\title{
Neglected obstructive pneumonia
}

\author{
Matteo Boattini, ${ }^{1}$ Nuno Costa, ${ }^{2}$ Nicole Murinello, ${ }^{3}$ Rogerio Matos ${ }^{3}$
}

1 Department of Internal Medicine, Santa Marta's Hospital, Lisbon, Portugal ${ }^{2}$ Department of Radiology, Santa Marta's Hospital,

Lisbon, Portugal

${ }^{3}$ Department of Pneumology, Santa Marta's Hospital, Lisbon, Portugal

\section{Correspondence to} Dr Matteo Boattini, matteoboattini@gmail.com
To cite: Boattini $\mathrm{M}$, Costa N, Murinello N, et al. BMJ Case Reports Published online: 14 December 2012 doi:10.1136/bcr-2012007270

\section{DESCRIPTION}

A 68-year-old man with type 2 diabetes mellitus, hypertension and history of laryngeal cancer surgery with tracheostomy was operated on in 1993 and right chest rib chondrosarcoma surgery was performed in 1997. The patient presented with fever and acute right sided hypochondrium pain. Lung examination showed decreased breath sounds over the right posterior of the lower chest. Blood examination revealed elevation of inflammatory markers. Chest radiography showed right inferior lung lobe (RILL) consolidation and he was admitted due to community acquired pneumonia suspect.

Chest CT revealed a foreign body (FB) not visible on the chest $\mathrm{X}$-ray in the inferior right stem bronchus (black arrow, figure 1) complicated by an endobronchial mass (EM, black star, figure 1), pleural effusion (red star, figure 1) and RILL

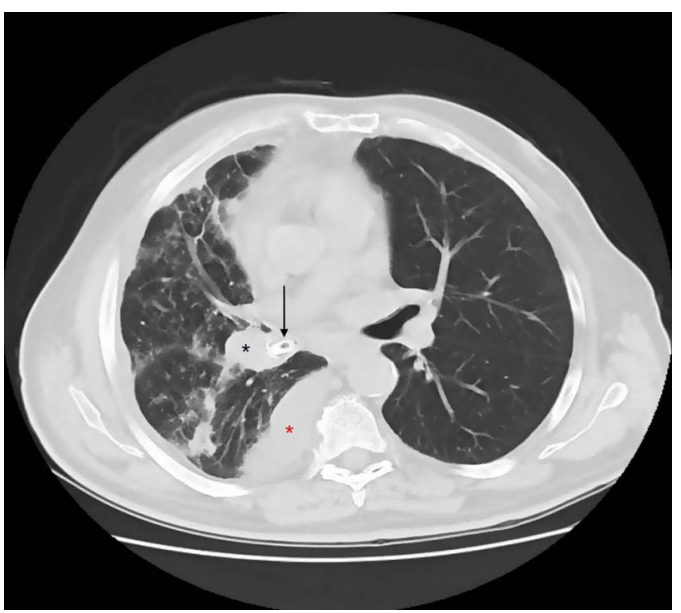

Figure 1 Chest CT showing foreign body (black arrow), endobronchial mass (black star) and pleural effusion (red star). atelectasis. Neither history of FB aspiration (FBA) nor FBA-related chronic symptoms ${ }^{1}$ such as cough, haemoptysis, dyspnoea, wheeze or recurrent pneumonia were recalled by the patient.

Flexible bronchoscopy was performed and the voice prosthesis was extracted (figure 2). Finally, the patient confessed that he had lost it about 1 year back.

EM biopsy revealed a granulation tissue. The patient was treated with piperacilin/tazobactam and short course of corticosteroids showing rapid improvement with significant EM size reduction.

Although more common in children, FBA may occur at any age and the diagnosis is significantly delayed in adults. ${ }^{1}$ Diagnosing airway FB with obstructive pneumonia is challenging because the nature of the FB is highly variable, the clinical and radiological findings are frequently non-specific ${ }^{2}$ and the patients do not always report history of choking. ${ }^{3}$

\section{Learning points}

- Foreign body aspiration is more common in children than in adults but the diagnosis in adults is frequently overlooked.

- Although it has not been validated a short course of corticosteroids usually results in the resolution of inflammatory endobronchial mass.

- The diagnosis of foreign body airway with obstructive pneumonia is often delayed because the patients do not always report history of choking.

\section{Competing interests None.}

Patient consent Obtained.

Provenance and peer review Not commissioned; externally peer reviewed.

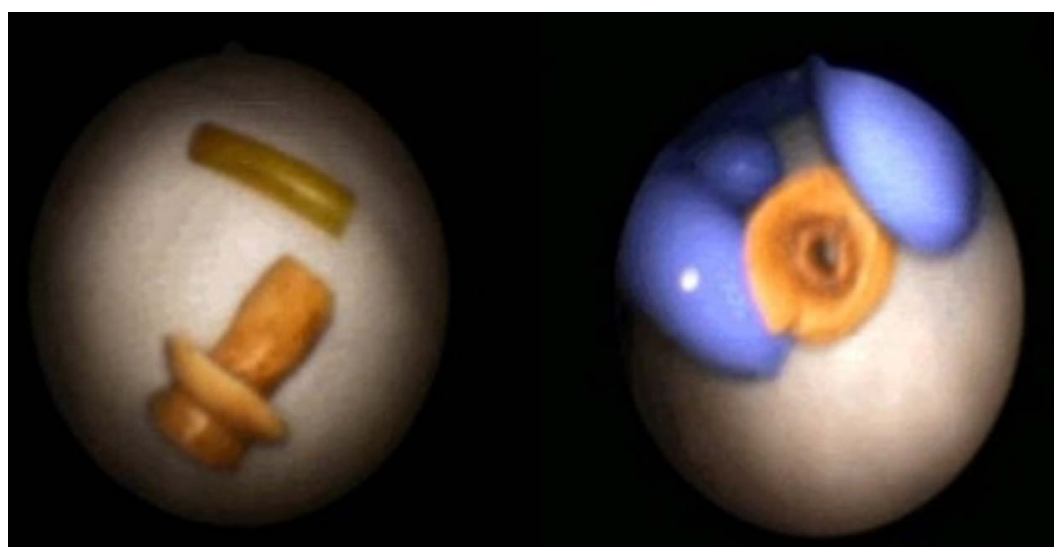

Figure 2 The voice prosthesis extracted by flexible bronchoscopy. 


\section{REFERENCES}

1 Baharloo F, Veyckemans F, Francis C, et al. Tracheobronchial foreign bodies: presentation and management in children and adults. Chest 1999; 115:1357-62.
2 Rafanan AL, Mehta AC. Adult airway foreign body removal. What's new? Clin Chest Med 2001;22:319-30.

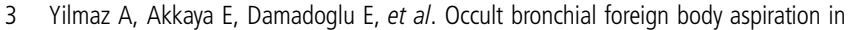
adults: analysis of four cases. Respirology 2004;9:561-3.

Copyright 2012 BMJ Publishing Group. All rights reserved. For permission to reuse any of this content visit

http://group.bmj.com/group/rights-licensing/permissions.

BMJ Case Report Fellows may re-use this article for personal use and teaching without any further permission.

Become a Fellow of BMJ Case Reports today and you can:

- Submit as many cases as you like

- Enjoy fast sympathetic peer review and rapid publication of accepted articles

- Access all the published articles

- Re-use any of the published material for personal use and teaching without further permission

For information on Institutional Fellowships contact consortiasales@bmjgroup.com

Visit casereports.bmj.com for more articles like this and to become a Fellow 